\title{
The variability of common reed Phragmites australis (Cav.) Trin. ex Steudel populations growing in urban conditions
}

\author{
Maria Krzakowa, Hanna Jakubiak, Mirosława Kołodziejczak \\ Department of Genetics, Adam Mickiewicz University, Umultowska 89, \\ 61-614 Poznań, Poland \\ corresponding author, e-mail: krzakowa@amu.edu.pl
}

\begin{abstract}
Differences between 13 common reed (Phragmites australis) populations, growing in urban conditions within the town of Poznań (western Poland), are described by 8 morphological traits of panicles' variability and the frequency of peroxidase (dimeric and monomeric) allozymes. Values of morphological characters were processed statistically using agglomerative clustering by the closest neighbours (UPGMA) method based on Euclidean distances. Proteins were separated in the starch gel electrophoretic procedure, showing cathodic migration. Populations are polymorphic and have a certain level of heterozygosity. The level of populations' diversity $(\mathrm{DST}=0.097)$ is lower than the intra-population variability $(\mathrm{GST}=0.187)$. The gene flow between populations is rather low $(\mathrm{Nm}=1.090)$.
\end{abstract}

Key words: Phragmites australis, genetic variability, peroxidases, allozymes.

\section{Introduction}

The decay of common reed in natural water reservoirs of Europe, observed in the last decade, with parallel signs of the species expansion in other parts of the world, has brought about intensive investigations of the species (Van der Putten 1997; Clevering 1999).

Common reed is a variable species and has always been attracting the botanists' interest. The latter ones, aiming at introducing an order to the observed differences in the morphology and growth forms provided varieties with a taxonomic rank, e.g. distinguishing $P h$. australis var. stolonifera, Ph. australis var. rivularis, Ph. australis var. favescens $(2 \mathrm{n}=48)$ and $P h$. australis var. gigantissima $(2 n=96)$, even if no direct relations have been detected between conditions of biotypes and the ploidy level. Common reed can grow in extremely variable biotype conditions and different osmotic pressures, also on soils with a significant salt content (Strogonov et al. 1970; Hellings \& Gallagher 1992; Lisner \& Schierup 1997).
The interest in common reed caused that studies have been undertaken not only on the morphology (Kraska et al. 1986; Kraska \& Bobowicz 1987; Kühl et al. 1999; Krzakowa et al. 2003) but also on physiology (Armstrong \& Armstrong 1988; Armstrong et al. 1996; Gessner et al. 1996; Kühl \& Kohl 1993; Chambers et al. 1998; Cizkova \& Bauer 1998; Ye et al. 1998; Grunfeld \& Brix 1999; Klimes et al. 1999), genetics (Bahrman \& Gorenflot 1983; Hauber et al. 1991; Kühl \& Neuhans 1993; Neuhans et al. 1993; Krzakowa 1996; Kühl et al. 1999; Pellegrin \& Hauber 1999; Krzakowa \& Drapikowska 2000; Drapikowska \& Krzakowa 2008) and on ecology (Zeidler et al. 1994; Clevering 1999; Kühl 1999) of the species.

Despite the constant hazard to biotype conditions, which change under the influence of anthropopressure, common reed grows within the limits of the Poznan town in as many as 109 biotypes (Jackowiak 1993). The extensive representation of common reed in the town is supported by its favourable geographic location, within the macroregion of the Wielkopolskie Lakeland (Jackowiak 
1990). The region includes lowlands at the meander of the Warta River and the junction of the Warta-Odra Valley and the Torun-Eberswalde Valley. The area of the town encompasses three lakes: Lake Kierskie (309.2 ha), Lake Strzeszyńskie (32 ha), Lake Malta (70 ha) and some small water reservoirs.

Common reed is generally thought to spread mainly by vegetative propagation (Kühl et al. 1999). However, since common reed also reveals a significant ability to reproduce generatively (Krzakowa \& Drapikowska 2000), we decided to examine selected populations growing in urban conditions, in order to determine their genetic variability.

\section{Material and methods}

There are strong indications that common reed populations might be highly variable in respect of the clonal structure, therefore care was taken to ensure that the populations sampled were not connected with the water current. Mature panicles were collected in wintertime since the seed requires freezing and the ice table provided easy collection of randomly sampled panicles (30 from each population). The populations included those in: 1 - Lake Malta, 2 - the Ceglanka River, 3 - a water reservoir near Glinianka Str., 4 - the Młyński Pond, 5 - Lake Rudnicze, 6 - a pond by Hubalczyków Str., 7 - a water patch near Świątniczki Str., 8 - Łęgi Dębińskie, 9 - Różany Młyn, 10 - a water patch by Wołczyńska Str., 11 - Lake Strzeszyńskie, 12 - Lake Rusałka, 13 - Lake Kierskie. Each population was characterised according to eight panicle traits. The results of measurements were computed (using Statistica 7.1) for trait characteristics, multivariate analysis of variance and principal component analysis.

For description of genetic variability, seeds from individual panicles were sown in identical glasshouse conditions; and when the seedlings reached the stage of three leaves (after approximately 6 weeks), they were subject to electrophoretic analyses. Peroxidases were stained in the cathode side of gel (Krzakowa 1996).

For each locus, in every population Ho and He, e.i. the observed and expected heterozygosities were defined. Two indices were calculated over polymorphic loci: the inbreeding coefficient $(F)$ following Wright (1965) and the polymorphic index (Pg) according to Kahler et al. (1980). The gene flow, expressed as the average number of immigrants per generation $(\mathrm{Nm})$, was estimated based on the overall allelic differentiation among populations.

Genetic differences between populations were described by peroxidase allozyme (Gregorius 1978) and genotype frequencies (Hedrick 1971).

\section{Results and discussion}

Trait characteristics (Tab. 1) show that the measures of panicles are very variable in all characters. The correlation coefficient calculated for pairs of all traits (Tab. 2) indicate that the highest correlation was observed between the first two characters. The inter-population variability, based on panicle traits, was reflected by the scatter diagram (Fig.1) of the studied populations on the plane of the two Principal Component axes (in total $80.94 \%$ of the information). Populations are divided into three groups; the most dissimilar is population 10 . This separateness is mainly caused by the first trait, which in this population attains the highest values in comparison to other populations. Similarly, when relations between populations were characterised in the threedimensional (Fig. 2) discrimination space (in total 84.99\% of the information), population 10 is again very distant and populations 2 and 7, as well as populations 6 and 4 occupy nearer sites. Graphical presentation (Fig. 3) of populations' positions after the UPGMA procedure, based on Euclidean distances, shows tendency for clustering the populations into two main groups and population 10 is visibly different. It is probably caused by complex phenotypic traits, as this population is characterised the highest stalks and the largest panicles in comparison with other stands.

The electrophoretically separated allozymes migrated to the cathodal part of gel and pointed to the existence of three loci. Two of them ( $A$ and $C$ ) proved to be polymorphic, while the third locus $B$ was monomorphic (and was excluded from comparisons) in all populations. The band patterns in locus $A$ confirmed its dimeric behaviour (Krzakowa 1996). The allozyme band patterns in locus $C$ indicate its monomeric character, as usual in the case of peroxidases.

Populations differed in allele frequencies in each locus (Fig. 4). They permitted to construct a dendrite (Fig. 5), which clearly illustrates that the populations are connected by similar distances.

Frequencies of genotypes in investigated populations are illustrated by Figure 6. Populations are significantly polymorphic (Tab. 3). Population 10 was the most polymorphic in respect of locus $A$, while populations 2 and 12 show the highest values of $\mathrm{Pg}$ indices in locus $C$. Low Ho values caused that some populations reached high fixation index $F$, for example in locus $A$ for population $1(F=0.82)$, as well as in locus $C$ for population $2(F=0.94)$ and 7 $(F=0.86)$, suggesting a high level of inbreeding. Two monomorphic populations in respect of locus $C$ (populations 4 and 10) showed $F$ coefficient values $=1.00$.

When the populations were compared with each other based on genotype frequencies (Fig. 7), five populations clustered together, while the remaining 8 populations formed two sub-groups, each of them consisting of four elements. 
Table 1. Characteristics for 8 panicle traits of Phragmites australis

\begin{tabular}{|l|r|r|r|r|r|}
\hline \multicolumn{1}{|c|}{ Traits } & $\mathrm{x}$ & $\mathrm{SD}$ & $\mathrm{CV} \%$ & $x_{\min }$ & $x_{\max }$ \\
\hline Panicle length & 26.48 & 5.40 & 29.17 & 10.50 & 44.00 \\
Panicle spread & 22.80 & 5.67 & 32.19 & 9.50 & 46.00 \\
The number of lateral ramifications & 20.06 & 7.20 & 51.84 & 3.00 & 48.00 \\
The number of top ramifications & 6.57 & 3.67 & 13.51 & 2.00 & 20.00 \\
The total number of whorls & 8.42 & 2.83 & 8.06 & 3.00 & 17.00 \\
The number of lateral branches in the first whorl & 5.91 & 1.77 & 3.15 & 2.00 & 16.00 \\
The number of lateral branches in the second whorl & 4.91 & 1.71 & 2.93 & 2.00 & 12.00 \\
The number of lateral branches in the third whorl & 3.86 & 1.54 & 2.37 & 2.00 & 8.00 \\
\hline
\end{tabular}

Table 2. Correlation coefficients for 1-8 traits of the reed (Phragmites australis): $x$ - arithmetic means, SD - standard deviations, $\mathrm{CV}$ - variability coefficient, $x_{\min }-$ minimum and $x_{\max }$ - maximum values respectively, at $\alpha=0.05$ level of significant correlation $\left({ }^{* *}\right)$

\begin{tabular}{|c|c|c|c|c|c|c|c|}
\hline & 2 & 3 & 4 & 5 & 6 & 7 & 8 \\
\hline 1 & $0.80^{* *}$ & $0.41^{* *}$ & -0.08 & $0.40^{* *}$ & $0.37^{* *}$ & $0.36^{* *}$ & $0.37^{* *}$ \\
\hline 2 & & $0.34^{* *}$ & $-0.18^{* *}$ & $0.40^{* *}$ & $0.40^{* *}$ & $0.39^{* *}$ & $0.41^{* *}$ \\
\hline 3 & & & $-0.31^{* *}$ & 0.00 & $0.25^{* *}$ & $0.16^{* *}$ & $0.15^{* *}$ \\
\hline 4 & & & & $-0.38^{* *}$ & $-0.29^{* *}$ & $-0.20^{* *}$ & $-0.23^{* *}$ \\
\hline 5 & & & & & $0.29^{* *}$ & $0.36^{* *}$ & $0.46^{* *}$ \\
\hline 6 & & & & & & $0.66^{* *}$ & $0.52^{* *}$ \\
\hline 7 & & & & & & & $0.71^{* *}$ \\
\hline
\end{tabular}

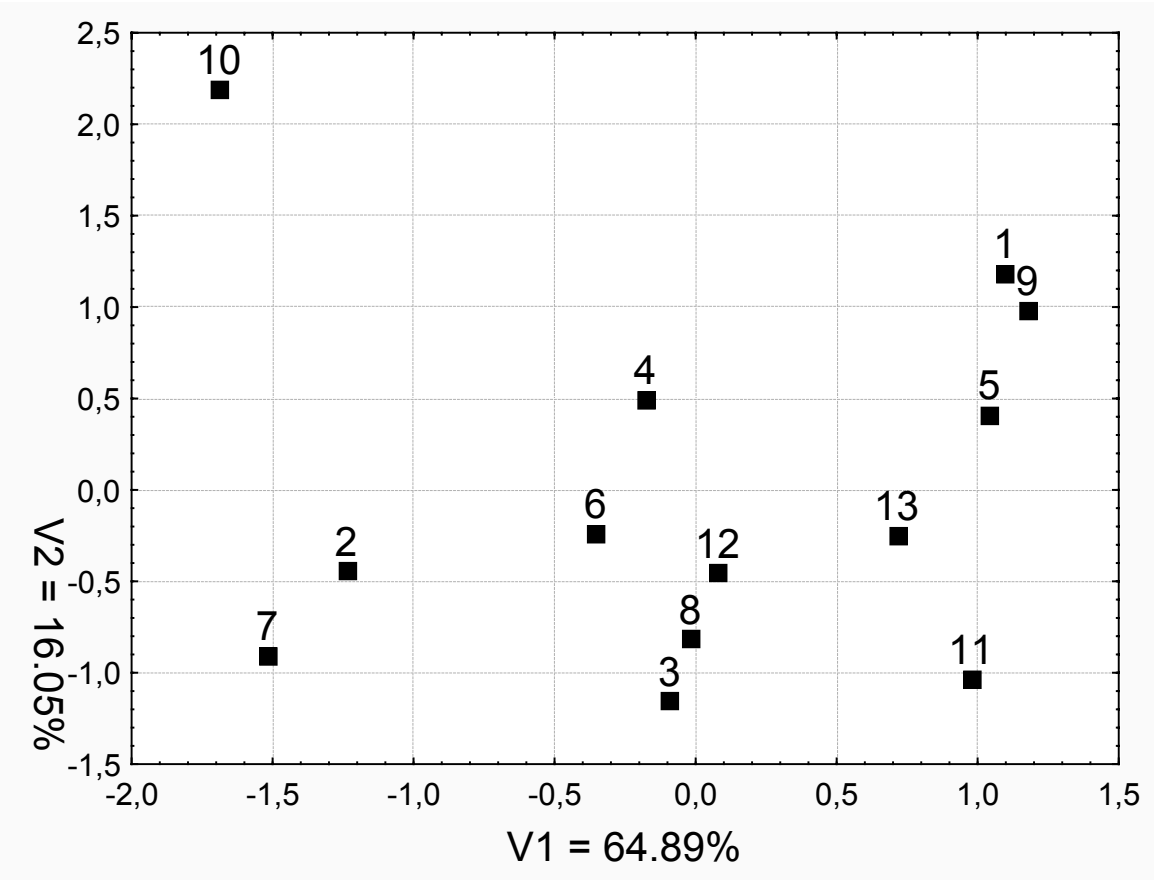

Figure 1. Scatter diagram for 13 reed populations on the plane of the two first principal components axes 
Table 3. Parameters of genetic variability coefficients of 13 reed populations: He - expected heterozygosity, Ho - observed heterozygosity, F - inbreeding coefficient, $\mathrm{Pg}$ - percentage of polymorphic loci

\begin{tabular}{|c|c|c|c|c|c|}
\hline Locus & Populations & He & Ho & F & Pg \\
\hline PXA & 01 & 0.3343 & 0.0606 & 0.8187 & 0.3893 \\
\hline PXA & 02 & 0.4352 & 0.5600 & -0.2868 & 0.5248 \\
\hline PXA & 03 & 0.4728 & 0.1667 & 0.6475 & 0.5978 \\
\hline PXA & 04 & 0.4978 & 0.5333 & -0.0714 & 0.6044 \\
\hline PXA & 05 & 0.4933 & 0.6538 & -0.3253 & 0.5059 \\
\hline PXA & 06 & 0.4644 & 0.4000 & 0.1388 & 0.6244 \\
\hline PXA & 07 & 0.4638 & 0.2692 & 0.4195 & 0.6243 \\
\hline PXA & 08 & 0.4328 & 0.3667 & 0.1528 & 0.5978 \\
\hline PXA & 09 & 0.4950 & 0.6000 & -0.2121 & 0.5550 \\
\hline PXA & 10 & 0.5000 & 0.4400 & 0.1200 & 0.6496 \\
\hline PXA & 11 & 0.3848 & 0.1200 & 0.6881 & 0.4832 \\
\hline PXA & 12 & 0.4352 & 0.2400 & 0.4485 & 0.5888 \\
\hline PXA & 13 & 0.4712 & 0.4400 & 0.0662 & 0.6208 \\
\hline PXC & 01 & 0.4642 & 0.1818 & 0.6083 & 0.5859 \\
\hline PXC & 02 & 0.6584 & 0.0400 & 0.9392 & 0.6816 \\
\hline PXC & 03 & 0.0950 & 0.0333 & 0.6491 & 0.1267 \\
\hline PXC & 04 & 0.2778 & 0.0000 & 1.0000 & 0.2778 \\
\hline PXC & 05 & 0.3913 & 0.1154 & 0.7051 & 0.4822 \\
\hline PXC & 07 & 0.5658 & 0.0769 & 0.8641 & 0.6213 \\
\hline PXC & 08 & 0.6528 & 0.2667 & 0.5915 & 0.7822 \\
\hline PXC & 09 & 0.5237 & 0.2500 & 0.5227 & 0.6400 \\
\hline PXC & 10 & 0.2112 & 0.0000 & 1.0000 & 0.2112 \\
\hline PXC & 11 & 0.5976 & 0.2000 & 0.6653 & 0.7104 \\
\hline PXC & 12 & 0.4856 & 0.5200 & -0.0708 & 0.6720 \\
\hline PXC & 13 & 0.3648 & 0.4000 & -0.0965 & 0.5248 \\
\hline PXC & 06 & 0.0000 & 0.0000 & & $0.00000 ”$ \\
\hline
\end{tabular}

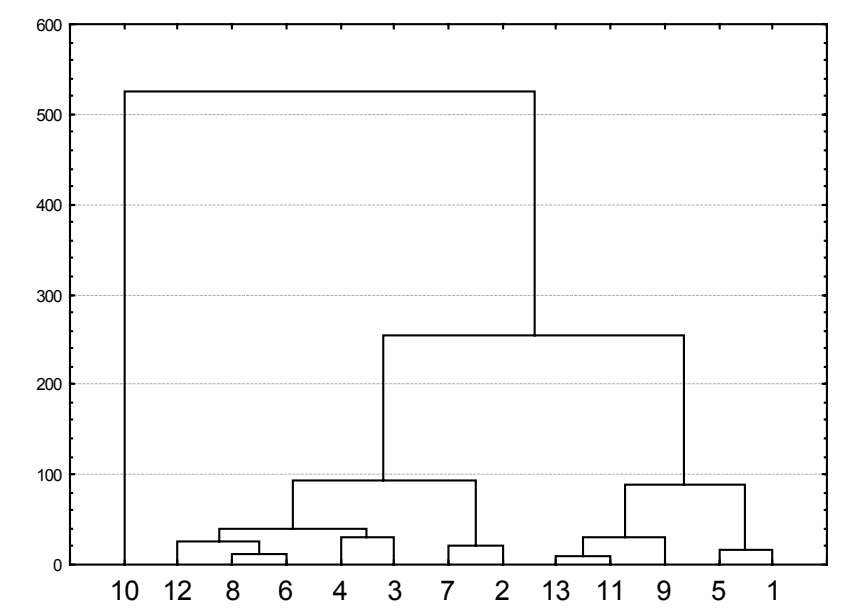

Figure 3. UPGMA clustering of 13 populations of Phragmites australis based on Euclidean distances 

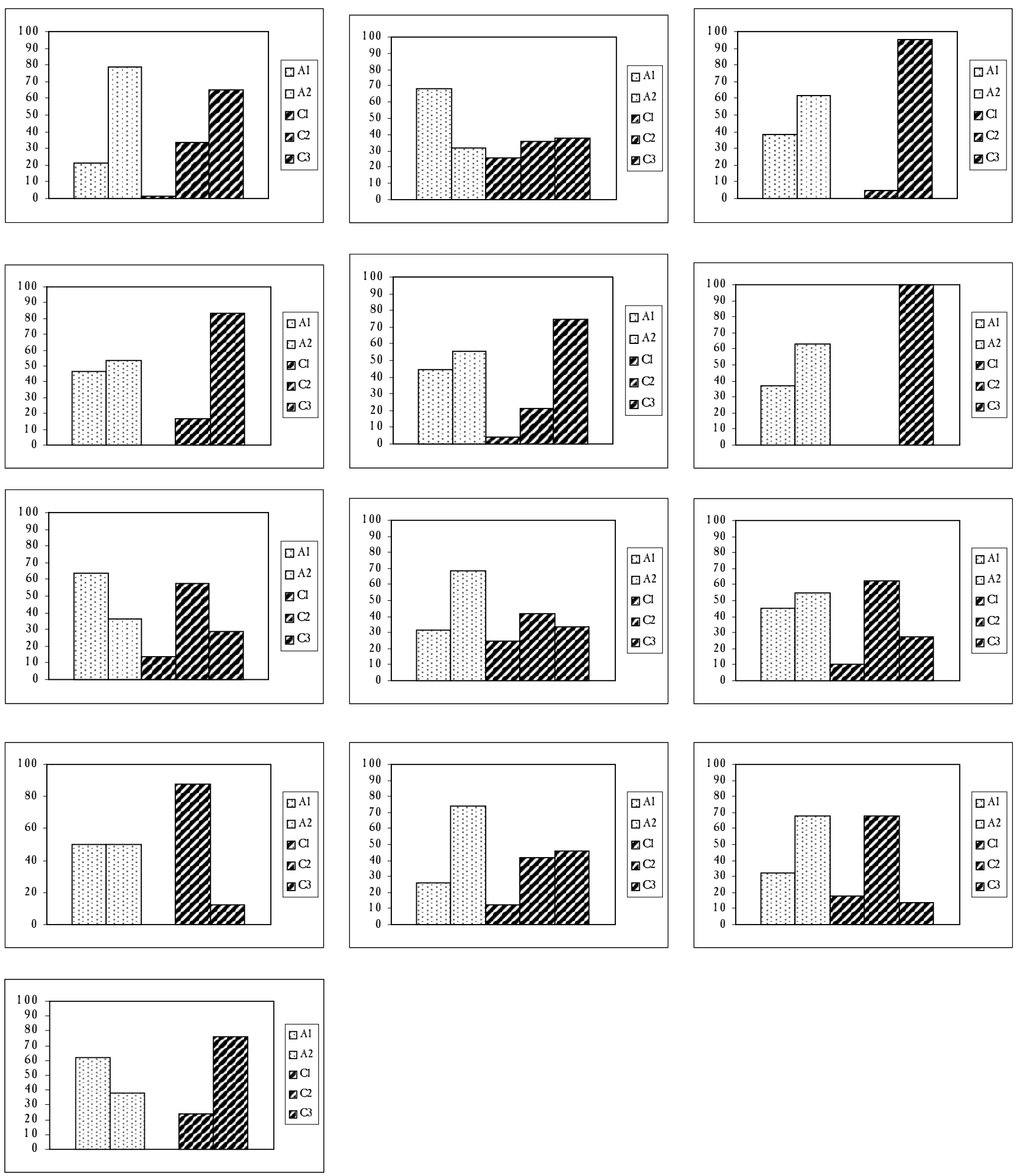

Figure 4. Histograms of allozymes frequency in 13 populations investigated 


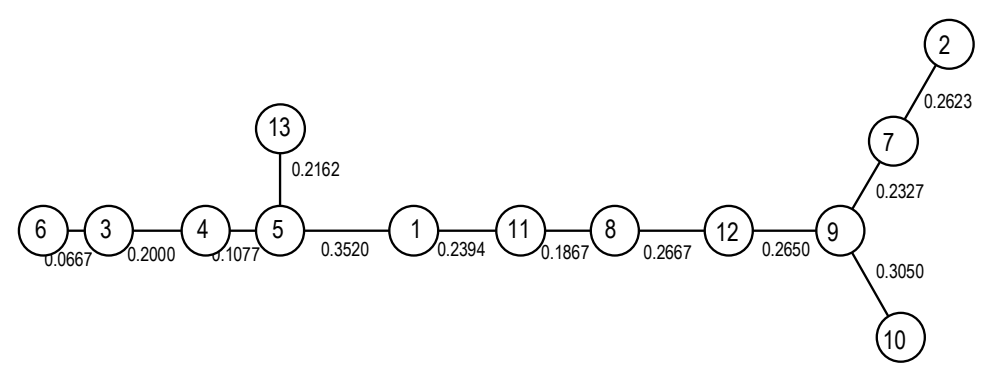

Figure 5. Minimum spanning tree for 13 examined populations of Phragmites australis constructed on the basis of genetic distances after Gregorius (1978)
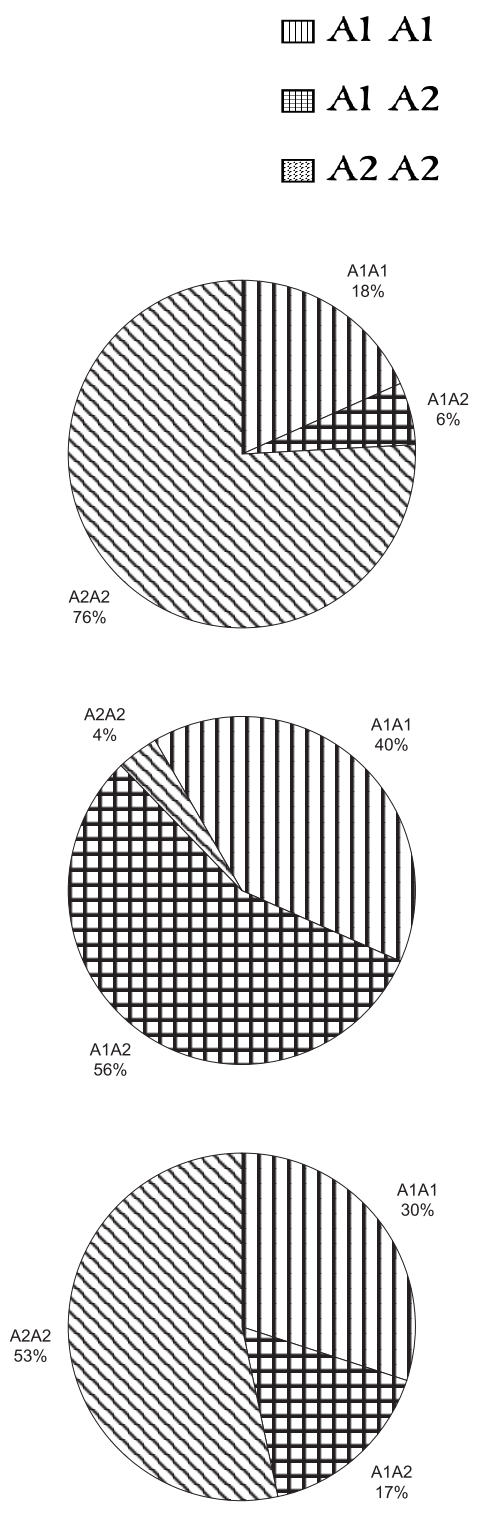

血 $\mathrm{Cl}$ C1

血 $\mathrm{Cl}$ C2

感 $\mathrm{C} 1 \mathrm{C} 3$

罝2 2 2

$\square \mathrm{C} 2 \mathrm{C3}$

$\square \mathrm{C3C3}$

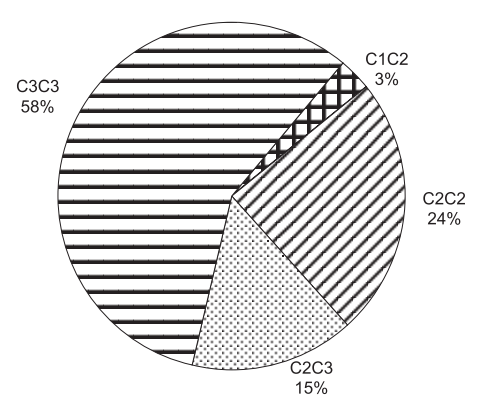

1

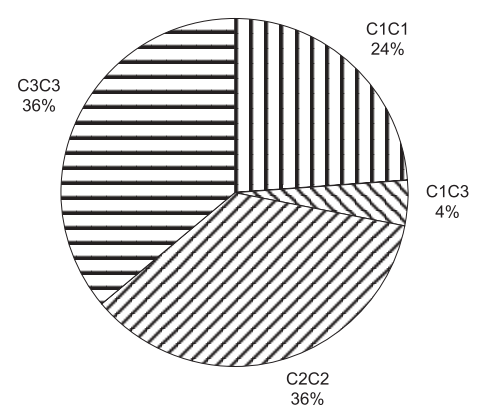

2

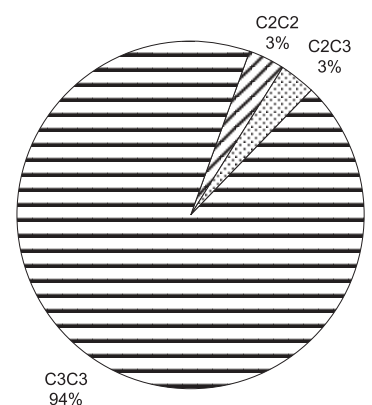

3

Figure 6. Diagrams of genotypes frequency in 13 populations of Phragmites australis 

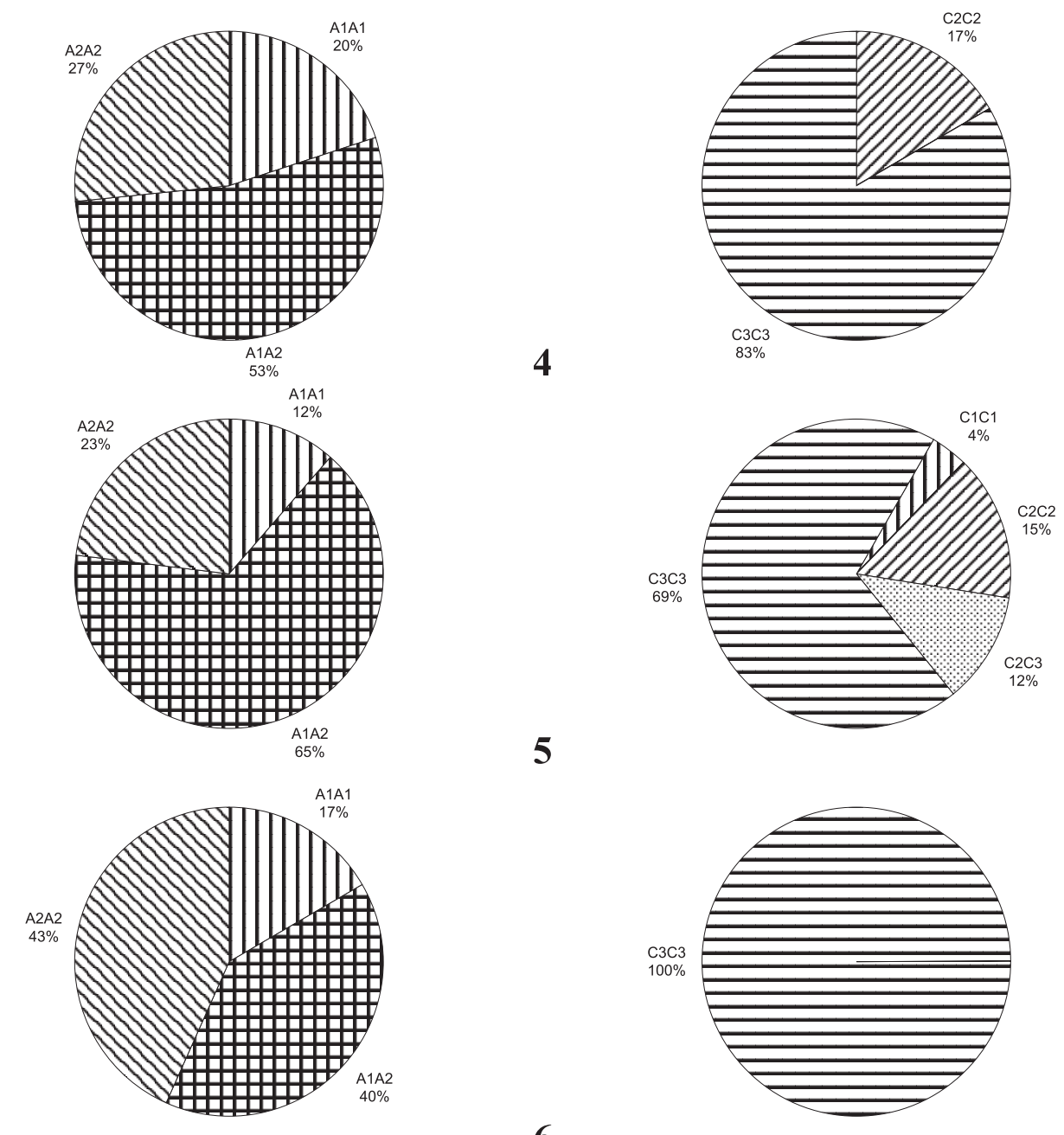

6
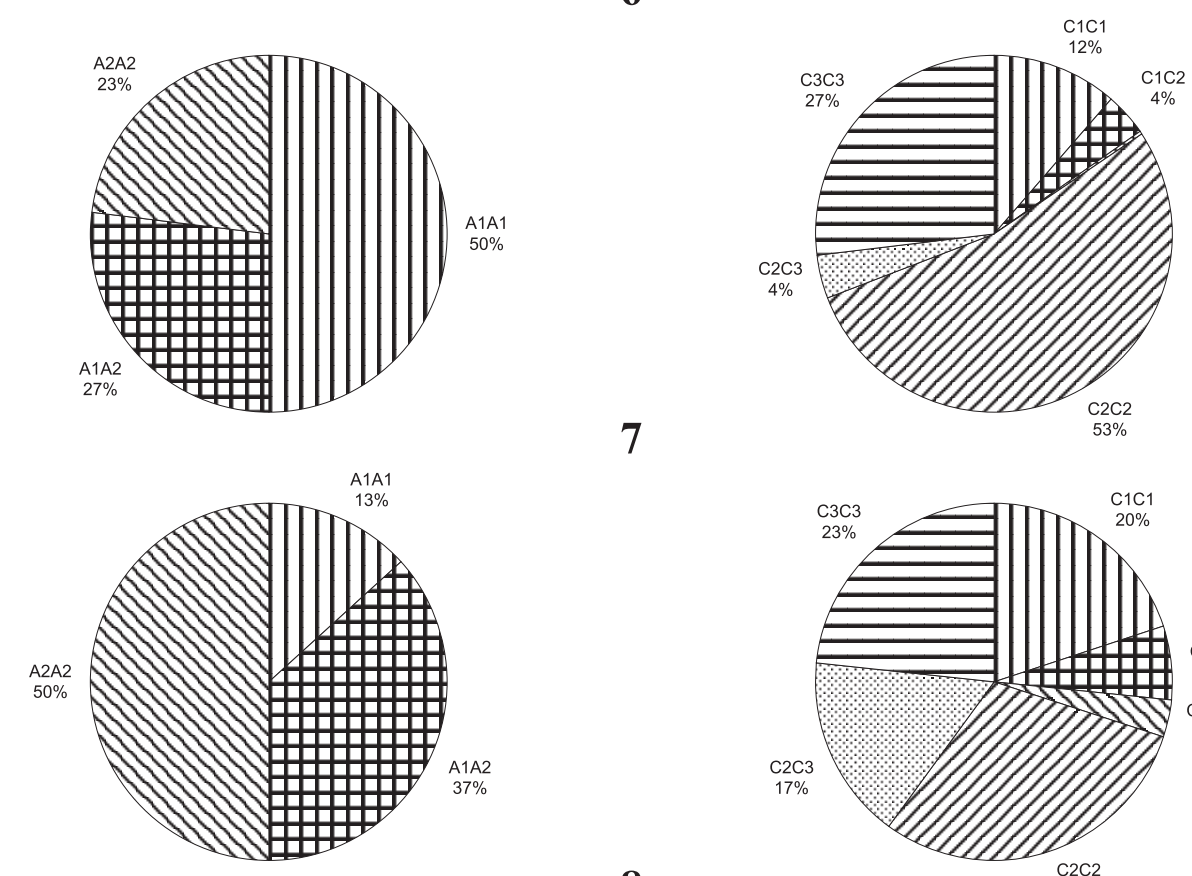

7

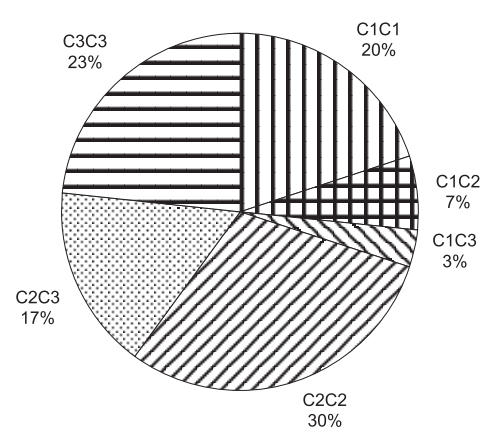

Figure 6. Diagrams of genotypes frequency in 13 populations of Phragmites australis 

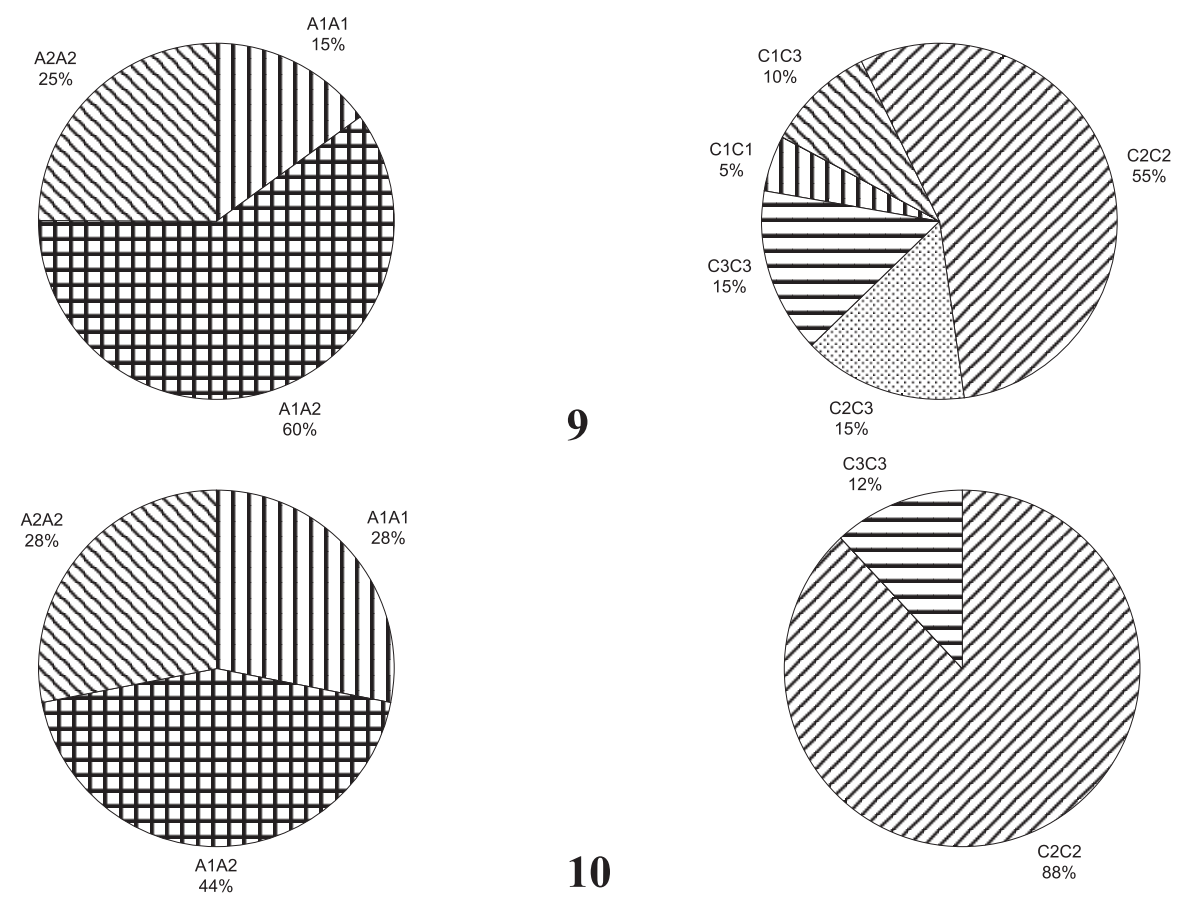

9
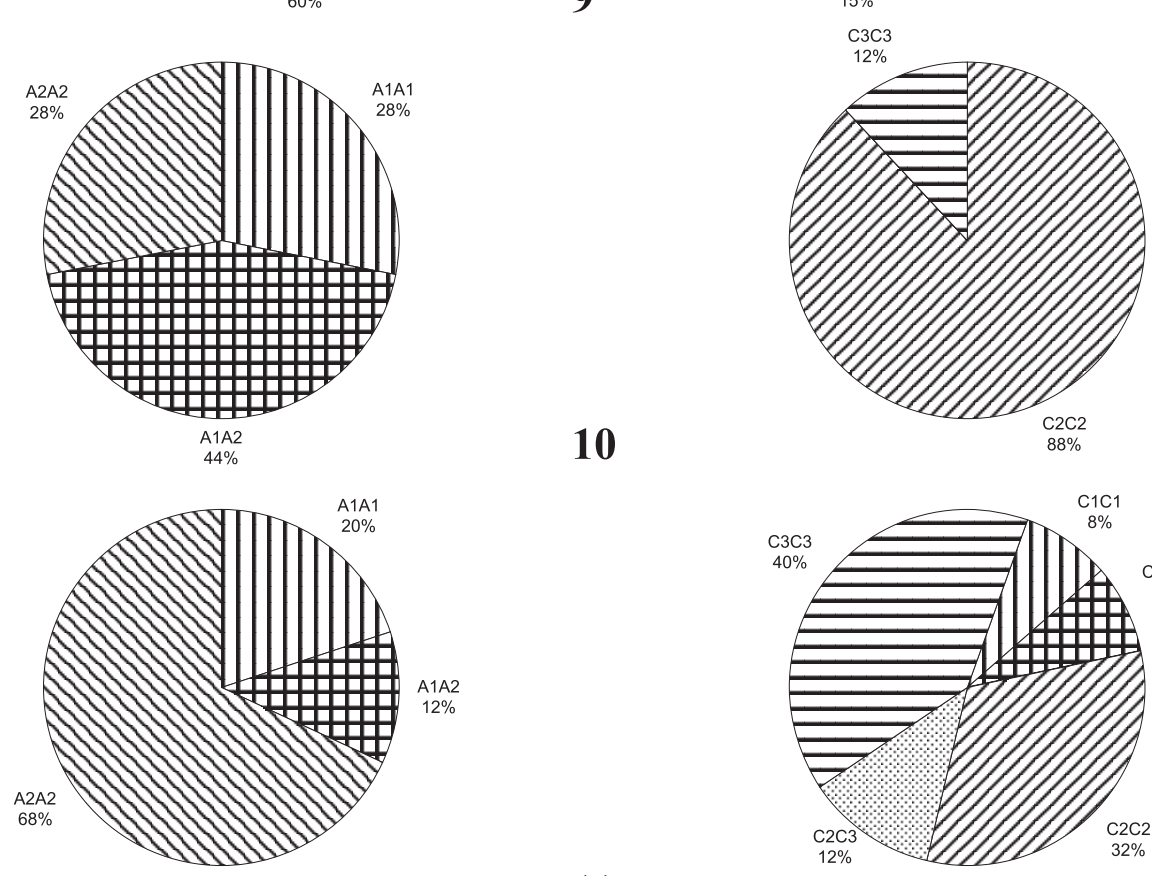

10
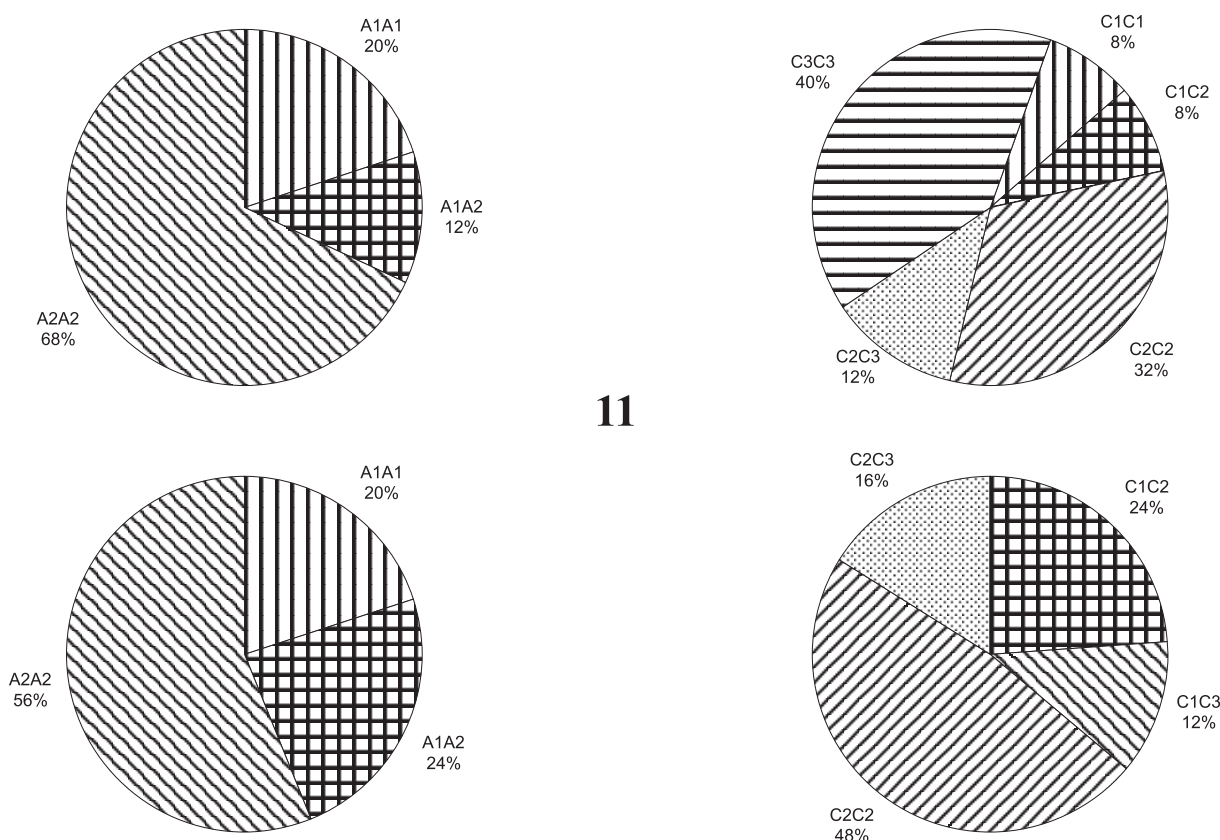

11
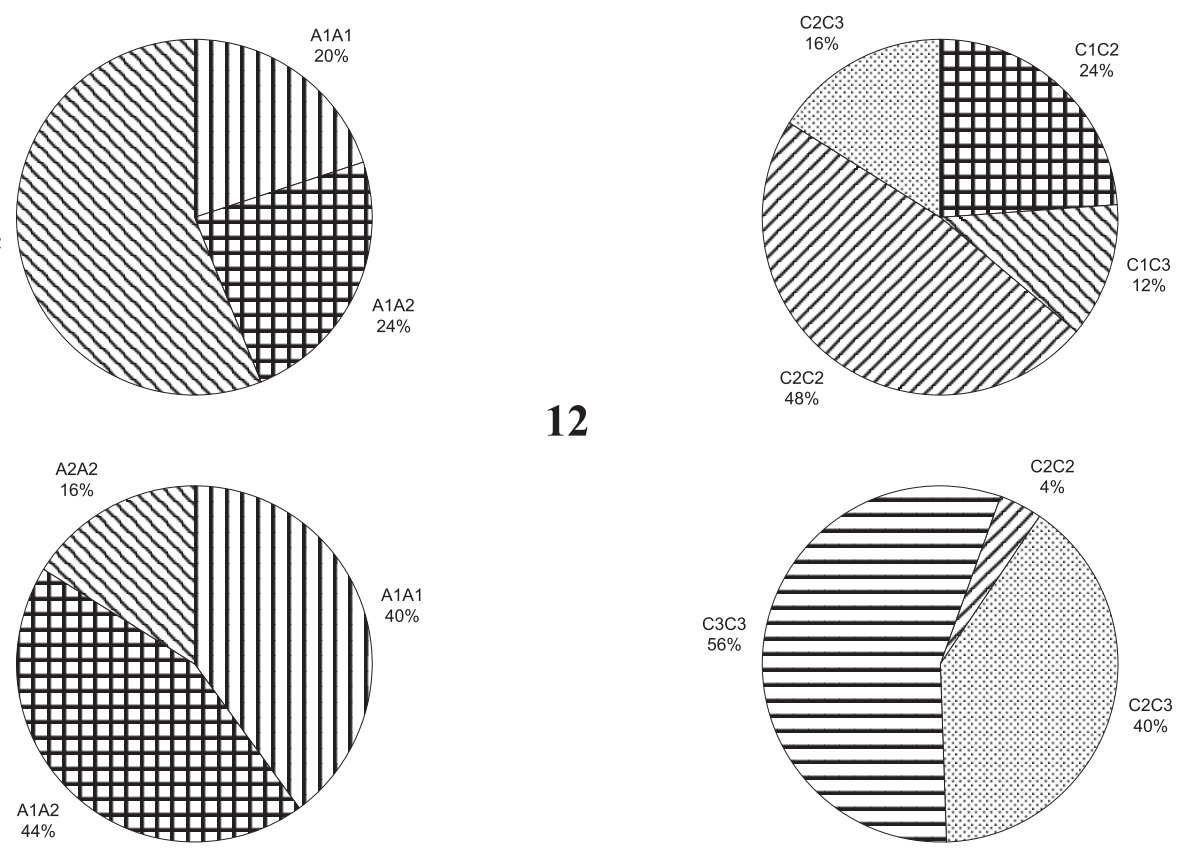

12

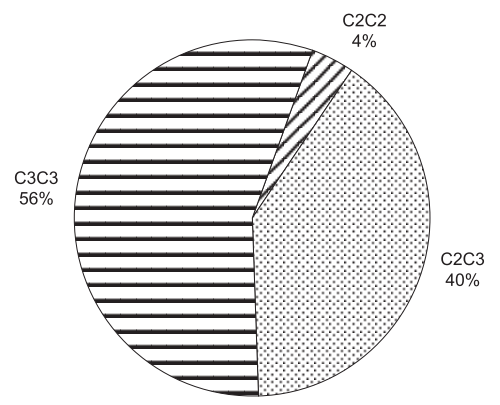

13

Figure 6. Diagrams of genotypes frequency in 13 populations of Phragmites australis 


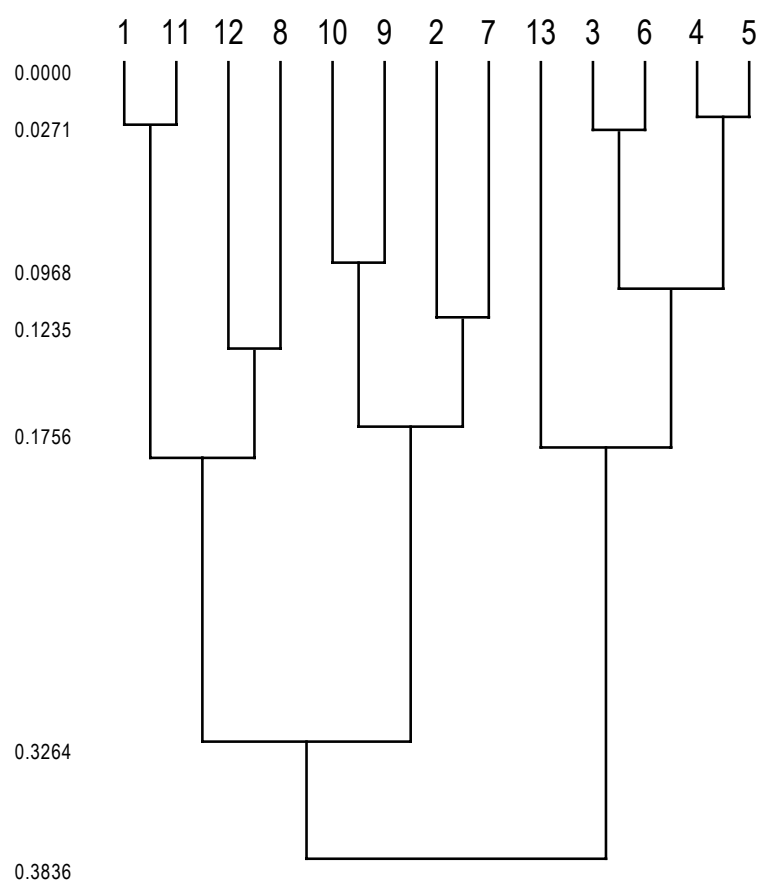

Figure 7. UPGMA cluster analysis of Hedrick's distances based on genotypes frequency

The inter-population differences pointed out a significant effect of generative reproduction on the population genetic structure. The level of diversity among populations (mean DST $=0.0973$ ) is lower as compared to intra-population variability $(\mathrm{GST}=0.1866)$. It is also interesting that the gene flow between populations was relatively low $(\mathrm{Nm}=1.090)$. In such situation, when the gene flow is limited, adaptive divergence to different selective environments may occur (Schluter 2000). It might concern common reed populations growing in different environments and distributed across an ecological gradient.

Some populations, which demonstrate a low polymorphism level, are probably composed of few clones, which in the case of small water reservoirs are exchanging alleles between the same genotypes quite frequently and what more, might simulate self-fertilization in this way. It can also be explained by the "founder effect".

Dimeric peroxidases are rare in the plant kingdom. One of such interesting cases involves dimeric peroxidases in Oryza sativa (Shahi et al. 1969; Pai et al. 1973) and Phragmites australis (Krzakowa 1996). Since both species grow in similar aquatic conditions, it is very possible that this trait carries some similar physiological importance of a common, unrecognised origin.

\section{Acknowledgements}

Thanks are due to Mrs Barbara Malchrowicz for her valuable technical assistance.

\section{References}

Armstrong J. \& Armstrong W., 1988, Phragmites australis - a preliminary study of soil - oxidizing sites and internal gas transport pathways, New Phytol. 108: $373-382$.

Armstrong J., Armstrong W. \& Van der Putten W. H., 1996, Phragmites die-back: bud and root death, blockages within the aeration of vascular systems and the possible role of phytotoxins, New Phytol. 133: 399-414.

Bahrman N. \& Gorenflot R., 1983, Appart des proteines foliares solubles dans l'interpretation du complexe poly- 
ploide du Phragmites australis (Cav.) Trin. ex Steudel Rev. Gen. Bot. 90: 177-184.

Chambers R. M., Mozdzer T. J. \& Ambrose J. C., 1998, Effects of salinity and sulfide on the distribution of Phragmites australis and Spartina alterniflora in a tidal saltmarsh, Aquat. Bot. 62: 161-169.

Cizkova H. \& Bauer V., 1998, Rhizome respiration of Phragmites australis: effects of rhizome age, temperature and nutrient status of the habitat, Aquat. Bot. 61: $239-253$.

Clevering O. A., 1999, The effect of litter on growth and plasticity of Phragmites australis clones originating from infertile, fertile or eutrophicated habitats, Aquat. Bot. 64: 35-50

Drapikowska M., Krzakowa M., 2008, Morphological and biochemical variation among common reed (Phragmites australis) populations in northwest Poland, oceanological and Hydrobiological Studies 37, Suppl. 1: 1-10.

Gessner M. O., Schüeferstein B., Müller U., Berkmann S. \& Lenfers U. A., 1996, A partial budget of primary organic carbon flows in the littoral zone of a hardwater lake, Aquat. Bot. 55: 93-105.

Gregorius H. R., 1978, On the concept of genetic diversity and differentiation, Theor. Appl. Genet. 74: 397-401.

Grunfeld S. \& Brix H., 1999, Methanogenesis and methane emissions: effect of water table, substrate type and presence of Phragmites australis, Aquat. Bot. 64: 63-75.

Hauber D. P., White A. \& Powers S. P., 1991, Isozyme variation and correspondence with unusual infrared reflectance patterns in Phragmites australis (Poaceae), Pl. Syst. Evol. 178: 1-8.

Hedrick P. W., 1971, A new approach to measuring genetic similarity, Evolution 25: 276-280.

Hellings S. E. \& Gallagher J. L., 1992, The effect of salinity and flooding on Phragmites australis, J. Appl. Ecol. 29: $41-49$.

Jackowiak B., 1990, Antropogeniczne przemiany flory roślin naczyniowych Poznania [Anthropogenic changes of the flora of vascular plants in Poznań], Wydawnictwo Naukowe UAM, Poznań.

Jackowiak B., 1993, Atlas of distribution of vascular plants in Poznań, Publications of the Department of Plant Taxonomy of the Adam Mickiewicz University in Poznań, No. 2, Polish/English text.

Kahler A. L., Allard R. W., Krzakowa M., Wehrhan C. F. \& Nevo E., 1980, Associations between isozyme phenotypes and environment in the slender wild oat (Avena barbata) in Israel, Theor. Appl. Genet. 56: 31-47.

Klimes L., Klimesova J. \& Cizkova H., 1999, Carbohydrate storage in rhizomes of Phragmites australis: the effect of altitude and rhizome age, Aquat. Bot. 64: $105-110$.

Kraska M., Bobowicz M. \& Arczyńska E., 1986, Morphological differences between stands of Phragmites aus- tralis (Cav.) Trin. ex Steudel in cold and heated water of Pątnowskie Lake, determined by measurements of caryopses, Pol. Arch. Hydrobiol. 33: 192-210.

Kraska M. \& Bobowicz M., 1987, Biometric analysis of caryopses different stands of Phragmites australis (Cav.) Trin. ex Steudel, Arch. Hydrobiol. Beih. 27: 223-229.

Krzakowa M., 1996, Genetic diversity of Phragmites australis (Cav.) Trin. ex Steudel revealed by electrophoretically detected differences in peroxidases, [in:] C. Obinger, U. Ebermann, C. Penel, H. Greppin (eds.), Biochemistry and Physiology, University of Geneva, Geneva: 184-189.

Krzakowa M. \& Drapikowska M., 2000, Sexual reproduction of Phragmites australis (Poaceae) in Baczkowski Pond (Poznań, Poland) revealed by peroxidase polymorphism, Poznań, Biol. Bull. 37: 43-53.

Krzakowa M., Kołodziejczak M., Drapikowska M. \& Jakubiak H., 2003, The variability of reed [Phragmites australis (Cav.) Trin. ex Steudel (Poaceae)] populations expressed in morphological traits of panicles, Acta Societatis Botanicorum Poloniae 72 (2): 157-160.

Kühl H., 1999, Transfer of results from reed research into practice as illustrated by reed protection measures in Berlin, Limnologica 29: 75-85.

Kühl H. \& Kohl J. G., 1993, Seasonal nitrogen dynamics in reed beds (Phragmites australis (Cav.) Trin. ex Steudel in relation to productivity, Hydrobiologia 251: 1-12.

Kühl H. \& Neuhaus D., 1993, The genetic variability of Phragmites australis investigated by random amplified polymorphic DNA, [in:] W. Osterdop \& P. Krumscheid-Plankert (eds.), Seeuferzerstörung und Seeuferrenaturierung in Mitteleuropa, Gustav Fisher Verlag, Stuttgard 5: 9-18.

Kühl H., Koppitz H., Rolletschek H. \& Kohl I. G., 1999, Clone specific differences in a Phragmites australis stand. I. Morphology, genetic and site description, Aquat. Bot. 64: 235-246.

Lissner J. \& Schierup H. H., 1997, Effects of salinity on the growth of Phragmites australis (Cav.) Trin. ex Steudel, Aquat. Bot. 55: 247-260.

Neuhans D., Kühl H., Kohl J. G., Dörfel P. \& Börner T., 1993, Investigations on the genetic diversity of Phragmites stands using genomic fingerprinting, Aquat. Bot. 45: 357-364.

Pai C., Endo T. \& Oka H. I., 1973, Genetic analysis for peroxidase isozymes and their organ specificity in Oryza perennis and O. sativa, Can. J. Genet. Cytol. 15: $845-853$.

Pellegrin D. \& Hauber D. P., 1999, Isozyme variation among populations of the clonal species, Phragmites australis (Cav.) Trin. ex Steudel., Aquat. Bot. 63: $241-259$ 
Schluter D., 2000, The Ecology of Adaptive Radiation, Oxford University Press, Oxford.

Shahi B. B., Chu Y. E. \& Oka H. J., 1969, Analysis of genes controlling peroxidase isozymes in Oryza sativa and $O$. perennis, Japan J. Genet. 44: 321-328.

Strogonov B. P., Kabanov V. V., Seviakova N. I., Lepina L. P., Komiserko E. J., Popov B. A., Dostanova R. CH. \& Prichodko L. S., 1970, Structure and function of plant cell under salinity, Moskow.

Wright S., 1965, The interpretation of population structure by F-statistics with special regard to systems of mating, Evolution 19: 395-420.
Van der Putten W. H., 1997, Die-back of Phragmites australis in European wetlands: an overview of the European Research Programme on "Reed Die-Back and Progression (1993-1994)", Aquat. Bot. 59: 263-275.

Ye Z. H., Wong M. H., Baker A. J. M. \& Willis A. J., 1998, Comparison of biomass and metal uptake between two populations of Phragmites australis grown in flooded and dry conditions, Ann. Bot. 82: 83-87.

Zeidler A., Schneider S., Jung C., Melchinder A. E. \& Dittrich P., 1994, The use of DNA fingerprinting in ecological studies of Phragmites australis (Cav.) Trin. ex Steudel, Botanical Acta 107: 237. 